\title{
Comparison of the Effectiveness of Different transcranial direct current stimulation Protocols (tDCS) with Cognitive Exercises in Improving Response Inhibition in Normal Individuals
}

\author{
Milad Amini Masouleh ${ }^{1}$, Samira Ghazanfariyan Pour ${ }^{2}$, Mansour Beirami ${ }^{3}$ \\ 1-MSc in Cognitive Science, Department of psychology, Faculty of Education \& Psychology. Azarbaijan Shahid \\ Madani University, Tabriz, Iran (Corresponding Author). ORCID: 0000-0002-7282-4370 \\ E-mail: milad.amini.ma@gmail.com \\ 2-PhD candidate in psychology, Department of psychology, Faculty of Education \& Psychology, Tabriz University, \\ Tabriz, Iran. ORCID: 0000-0002-3473-1974 \\ 3-professor of psychology, Department of psychology , Faculty of Education \& Psychology. Tabriz University, \\ Tabriz, Iran. ORCID: 0000-0002-5015-2585
}

Received: 23/01/2019

Accepted: 10/06/2019

\begin{abstract}
Introduction: Studies have shown that the anodal tDCS is able to increase the effectiveness of cognitive rehabilitation. On the other hand, results of recent studies have shown that unihemispheric concurrent dual-site a-tDCS could increase the corticospinal excitability.

Aim: The present study compares the effectiveness of unihemispheric concurrent dual-site atDCS and conventional tDCS, during cognitive exercises in improving the response inhibition of normal individuals.

Method: 21 subjects were randomly assigned into two experimental groups as well as a control group. First group received Anodal tDCS over the left DLPFC and M1, the second group received Anodal tDCS over the left DLPFC and Control group received sham a-tDCS. Transcranial direct current stimulation (tDCS) at $0.3 \mathrm{mAh}$ was applied directly for 30 minutes in 4 sessions. All subjects, after interventions in each session, performed the stop signal task. In Fifth session, In order to follow up the effectiveness of interventions, 24 hours after the interventions, subjects were re-evaluated.
\end{abstract}

Results: The results of repeated measurements analysis revealed that compared with conventional tDCS and control group, unihemispheric concurrent dual-site a-tDCS group had larger improvement in improving the response inhibition of normal individuals (P.05).

Conclusion: The results show that unihemispheric concurrent dual-site a-tDCS could enhance the effectiveness of cognitive exercises by increasing cortical excitability

Keywords: TDCS, Cognitive exercises, Response inhibition

How to cite this article : Amini Masouleh M, Ghazanfariyan Pour S, Beirami M. Comparison of the Effectiveness of Different transcranial direct current stimulation Protocols (tDCS) with Cognitive Exercises in Improving Response Inhibition in Normal Individuals. Shenakht Journal of Psychology and Psychiatry. 2019; 6 (3): 1-14 .URL: http://shenakht.muk.ac.ir/article-1-603-fa.pdf

Copyright $\odot 2018$ the Author (s). Published by Kurdistan University of Medical Sciences. This is an open access article distributed under the terms of the Creative Commons Attribution-Non Commercial License 4.0 (CCBY-NC), where it is permissible to download, share, remix, transform, and buildup the work provided it is properly cited. The work cannot be used commercially without permission from the journal. 


\title{
مقايسه ى اثربخشى يروتكلهاى مختلف تحريك الكتريكى مستقيم فرا جمجمه اى (TDCS) به

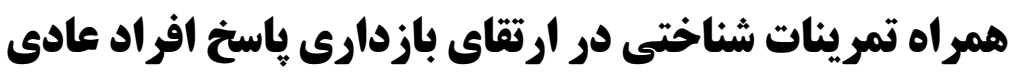

\author{
ميلاد امينى ماسوله '، سمير ا غضنفريان'، منصور بيرامى
}

ا. كارشناسى ارشد علوم شناختى ، كروه رواننشاسى، دانشكده علوم تربيتى و روانشناسى ، دانشكاه شهيد مدنى آذربايجان، تبريز ، ايران (مولف مسئول). ايميل: milad.amini.ma@gmail.com r. كانديداى روانشناسى ، گروه روانشناسى، دانشكده علوم تربيتى و روانشناسى ، دانشكاه تبر يز، تبريز ، ايران.

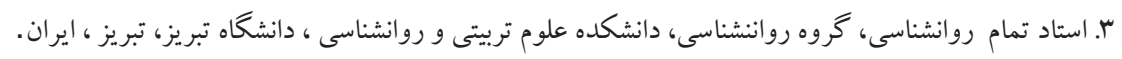

\section{جكيده}

مقدمه: يُزوهشها نشان دادند اعمال تحريك الكتر يكى مستقيم فرا جمجمه اى آنودال سبب افزايش اثربخشى توانبخشى شناختى مى

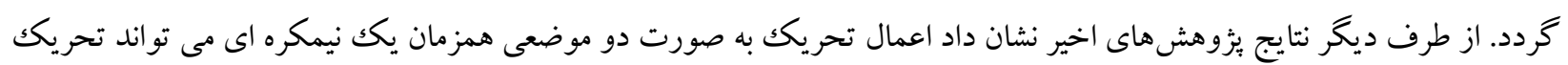

$$
\text { بذيرى قشرى-نخاعى را افزايش دهد. }
$$

هدف: يزوهش حاضر به مقايسه ى اثربخشى تحريكك الكتريكى مستقيم فرا جمجمه اى دو موضعى همزمان يكك نيمكره اى و تحريكك

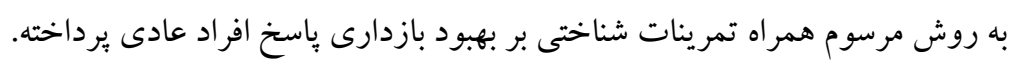

روش: اب آزمودنى به صورت تصادفى در دو گروه آزمايشى و كنترل شامل گروه اعمال تحريك الكتريكى مستقيم فرا جمجمه اى

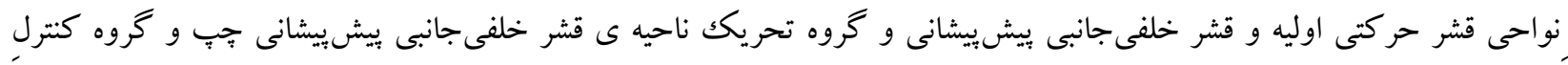

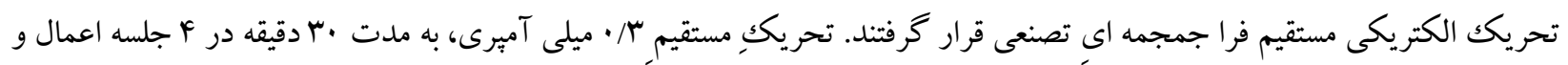

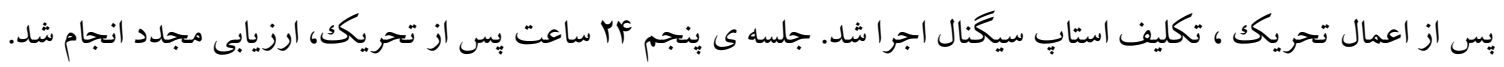
يافتهها: تحليل واريانس با اندازه گيرى هاى مكرر نشان داد، اعمال تحريك جريان مستقيم الكتريكى فرا جمجمهاى آنودال دو

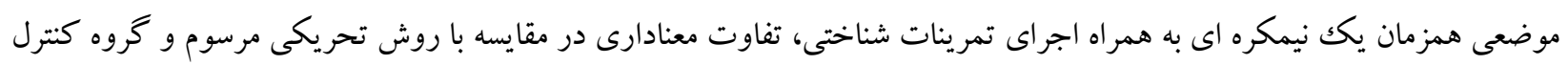

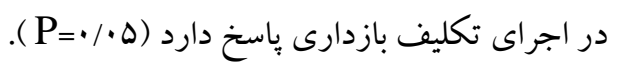

نتيجه كيرى: تحريك الكتريكى مستقيم فرا جمجمه اى آنودال دو موضعى همزمان يكك نيمكره اى از طريق افزايش تحريك يذيرى

$$
\text { قشرى، اثربخشى تمرينات شناختى را افزايش داد. }
$$

كليدوازهها: تحريكك جريان مستقيم الكتريكى فرا جمجمهاى ، تمرينات شناختى، بازدارى باسخ 
" إنايى رد نمودن" و خوددارى از يكك قصد و تمايل

مقله

خود كارانه) تعريف نمودهاند.

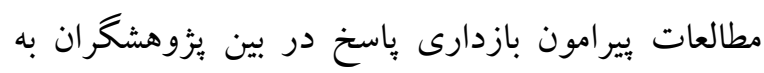

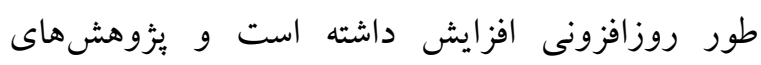
بسيارى در دهلى كذشته نشان دادهاند كه اين كاركرد، با افزايش فعاليت در نواحى يشتى - ميانى كورتكس برى

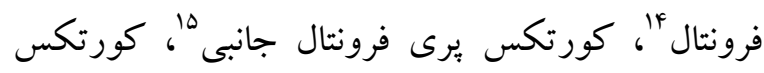

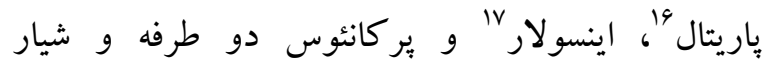

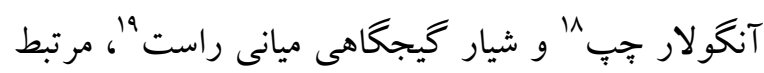

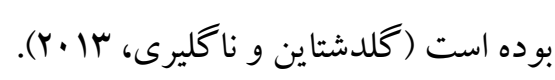

در سالهاى اخير، تكنيكهاى غيرتهاجمى تحريك مغزى مختلفى مورد استفاده قرار گرفته است كه مي تواندي منجر به تعديل در تحريككيذيرى و فعاليت كورتكسى و مختى مورد در نتيجه، ايجاد تغييرات در كاركردهاى شناختى و وله

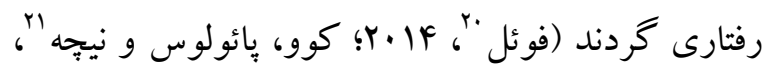

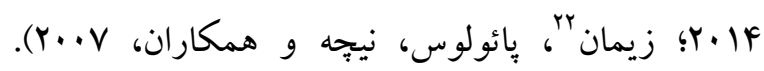
تحريك جريان مستقيم الكتريكى فرا جمجمهاى (tDCS)

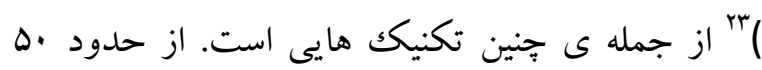
سال بيش نشان داده شده است كه به كارگيرى جريان هاى مستقيم زير آستانهاى و نسبتاً ضعيف بر بر روى لهاد كورتكس حيوانات مى تواند منجر به ايجاد تغييراتى قطبى در فعاليت كورتكسى و همجنين تحريكك يذيرى آن كردد كه مى تواند جِندين ساعت پِ بس از مداخله به طول

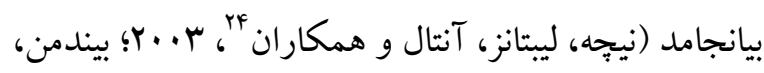

13 - reject

14 - dorsomedial prefrontal cortex

15 - lateral prefrontal cortex

16 - parietal cortex

17 - insular cortex

18 - left angular gyrus

19 - right middle temporal gyrus

${ }^{20}$ - Flöel

${ }^{21}$ - Kuo, Paulus \& Nitsche

22- Ziemann

23. Transcranial direct current stimulation

24- Liebetanz, Antal \& et al
كاركردهاى شناختى مجموعه توانايىهايى را در برمى گيرد كه ارتباط مستقيمى با فهم و ادراك وقايع زندگى روزمره و قابليت تصميم گيرى و انطباقيذيرى

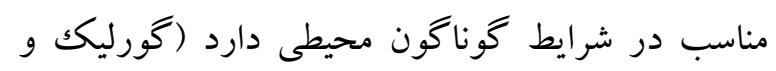

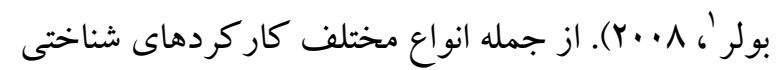
مىتوان كاركردهاى اجرايى را ذكر نمود كه اشاره به مجموعه عملكردهايى دارد كه مرتبط با فعاليت قشر بيش ييشانى 'مى باشند كه توانايى بايش و تعديل رفتار در حال وقوع را در موقعيتهاى شناختى، هيجانى و اجتماعى

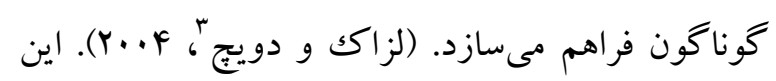
مفهوم مىتواند طيف وسيعى از كاركردهاى عالى

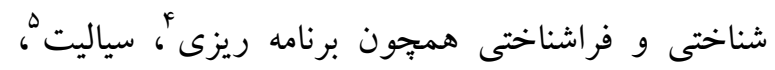

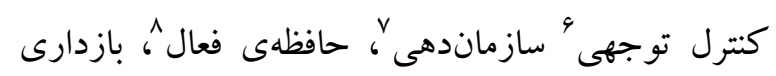

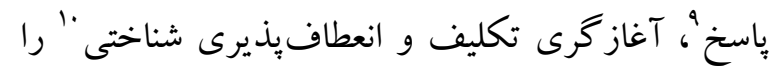

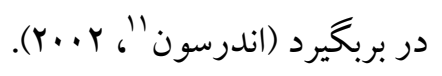

از اين ميان، بازدارى ياسخ اشاره به توانايى اداره و جهت

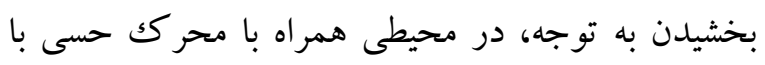
جشم يوشى از اطلاعات نامرتبط و حفظ توجه بر محر كى

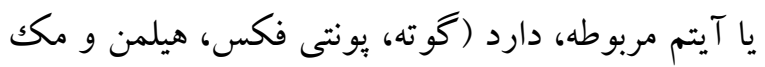

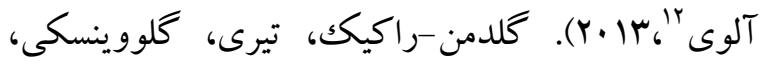

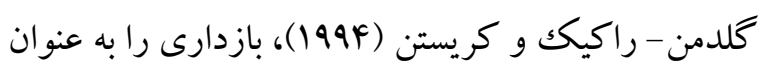

\footnotetext{
- Gorelick \& Bowler

2 - prefrontal cortex

3- Lezak \& Deutsch

4- planning

5 - fluency

${ }^{6}$-Attentional control

7-planning

8 - working memory

9 - responses

${ }^{10}$ - cognitive flexibility

11 - Anderson

12- Gothe, Pontifex, Hillman, McAuley
} 
جنين يروتكلى مى تواند تأثير معنادارى در بهبود عملكرد بيماران در مقايسه با گروه كنترل داشته باشد. از طرف ديكر، ئزوهشهاى اخير نشان دادهاند، هنگًامى كه تحريك الكتريكى مستقيم فرا جمجمهاى همراه با روشهاى تمرينى استاندارد و يا بروتكل هاى توانبخشى به كار مىرود؛ اثربخشى آنها به ميزان قابل توجهى در توانايى بازدارى بِاسخ افرايش مىيابد. يُزوهش هاى انجام

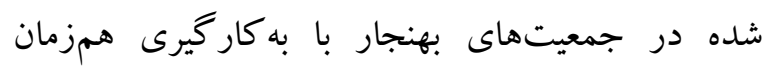

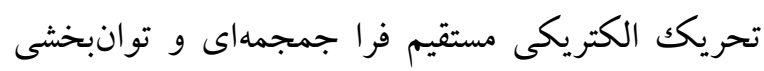
شناختى در يك جلسه، حاكى از اين بوده است كه لهر استفاده از جنين يروتكلى مىتواند عملكرد افراد در كاركردهاى شناختى همجيون حافظهى كارى، يادگيرى را به مدت كوتاهى افزايش دهد (فوئل، ساتورب؛، كول و

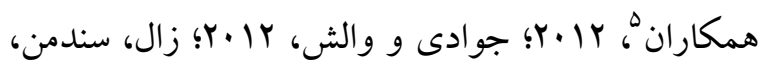
ثورن، جنك و هرمان؛

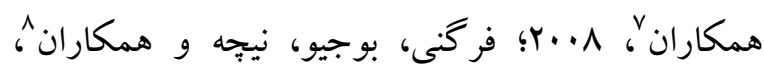

$$
.(Y \cdots \Delta
$$

در همين زمينه، ديتيه و همكاران (Y|Y.Y)، به بررسى اثربخشى اعمال همزمان تحريك الكتريكى مستقيم فرا جمجمهاى و توانبخشى شناختى مبتنى بر تكاليف كامييوترى بر توانايى بازدارى بِاسخ در افراد عادى

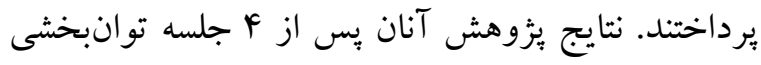
با استفاده از تكليف كامييوترى استاب سيخنال و اعمال تحريكك الكتريكى مستقيم فرا جمجمهاى بر روى ناحيهى شكنج بيشين قدامى (IFG) راست ج با شدت يكك و نيم ميلى آمير و به مدت ها دقيقه نشان داد كه اين بيروتكل

- Suttorp, Kohl \& et al

${ }^{6}$ - Zaehle, Sandmann, Thorne, Jäncke \& Herrmann

7. Ohn, Park, Yoo \& et al

${ }^{8}$-Fregni, Boggio, Nitsche \& et al

9 - right inferior frontal gyrus
لييولد و ردفيرن'، 1994). مطالعات مربوط به نمونهاى انسانى نيز نتايج فوق را مورد تائيد قرار داده است (نيجهه و

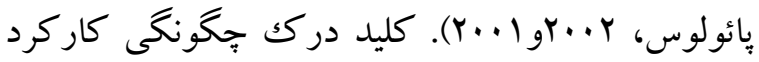
تكنولوزىهاى تحريك مغزى، فهم ساختار مدارگونه مغز است كه در كاركردهاى بهنجار و نابهنجار مغز نقش اساسى ايفا مى كند. در نتيجهى تحريك عصبى بهوسيلهى تحريكك مغزى، آبشارى از وقايع مولكولى روى مىدهد كه منجر به تغييرات عصبى درازمدتى بهخصوص در سطح سينايسى مى گردد كه مى توانند تا جند ساعت، روز و يا مدت طولانى ترى نسبت به طول تحريك وارد شده،

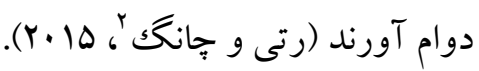

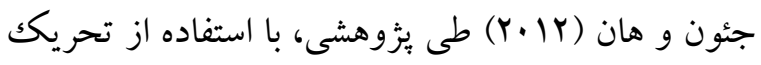
الكتريكى مستقيم فرا جمجمهاى را بر روى ناحيهى قشر خلفى جانبى بيش ييشانى جِب را تحريك نمودند. نتايج به

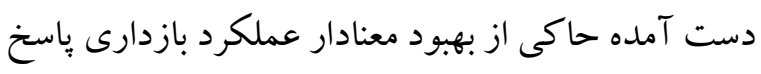
در تكليف استروب بود. به نظر مىرسد كه اين ناحيه در كاركردهاى مربوط به بازدارى ياسخ نقش عمدهاى ايفا نمايد.

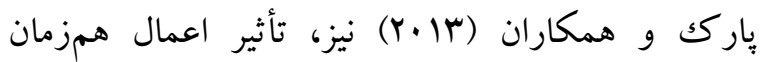
تمرينات كامييوترى شناختى و اعمال تحريك الكتريكى مستقيم فرا جمجمهاى آنودال با شدت جريان Y ميلى آمِر و به مدت ·r دقيقه بر روى ناحيهى قشر خلفى جانبى

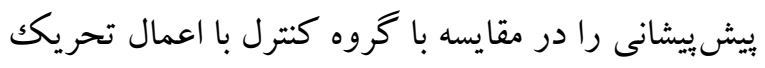

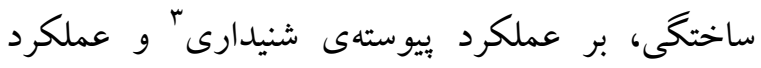

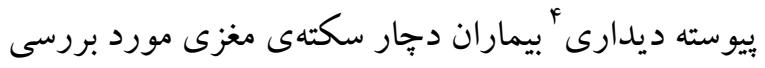
بررسى قرار دادند. نتايج يثوهش آنها IV جلسهى تو انبخشى به صورت ه مرتبه در هفته نشان داد كه اعمال

\footnotetext{
1- Bindman, Lippold \& Redfearn

7- Reti \& Chang

3 - auditory continuous performance

${ }^{4}$-visual continuous performance
} 
در اغلب يزوهشهايى كه در آنها تحريك الكتريكى

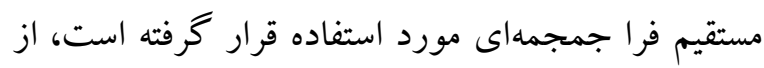
يك الكترود آنود و يك الكترود كاتود بر روى يوست

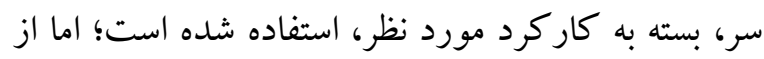
مونتازهاى ديكر همجون يكك الكترود آنود و دو الكترود

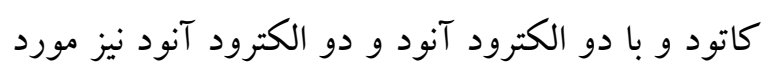
استفاده قرار گرفته است (اوتز، ديمووا، اوينلندر و و

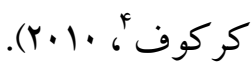
واثقى، ذوقى و جابرزاده، (1) (Y) در برُوهشى به مطالعهى تأثير تحريك همزمان كورتكس حركتى اوليه و نواحى

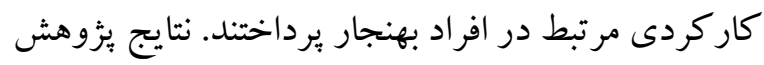
آنها حاكى از القاى بيشتر يتانسيلهاى فراخوانداني

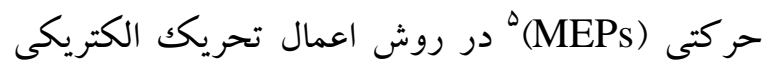
مستقيم فرا جمجمه اى آنودال به صورت دو موضعى

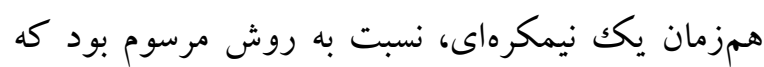
حداقل به مدت بF ساعت ادامه داشت. در همين راستا، مطالعهى اخير كو كلتا، دامبورسكا،

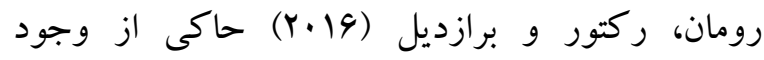
شواهدى دال بر نقش كاركردى مستقيم ناحيهى حر كتى اوليه در فعاليتهاى مختلف شناختى، علاوه بر بر

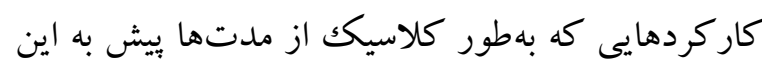
ناحيه نسبت داده مىشد بود. علاوه بر اين، ناحيهى

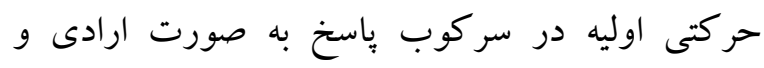

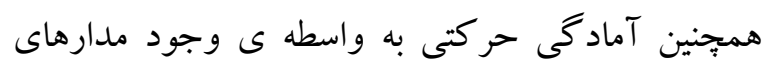
برنامه ريزى حر كتى، دخيل دانسته شده است (كن و و كن، وسن،

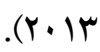
بنابراين به نظر مىرسد، اعمال همزمان تحريك آنودال در ناحيهى مربوطه و منطقهى كاركردى مرتبط به دليل

4- Utz, Dimova, Oppenländer \& Kerkhoff 5 - motor-evoked potentials
اثربخشى بيشتر نسبت به گروه كنترل همراه با تحريك ساختخى داشت.

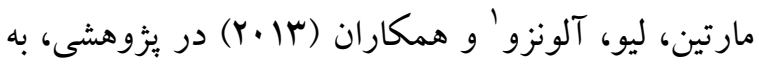

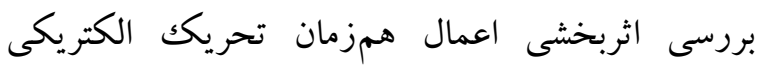
مستقيم فرا جمجمهاى و تمرينات كامييوترى شناختى بر فراري كاركردهاى اجرايى، حافظهى فعال، سرعت يردازش، توجه و زمان واكنش افراد عادى برداختند. اعمال تحريكك الكتريكى مستقيم فرا جمجمهاى به صورت آنودال و با شدت جريان r ميلى آمبر به مدت ·r دقيقه بر روى ناحيهى قشر خلفى جانبى ييشييشانى اعمال شد.

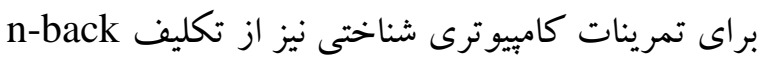

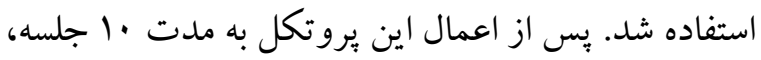

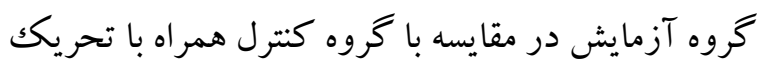
تصنعى، نتايج بهترى را در تكاليف حافظهى فعال و توجه

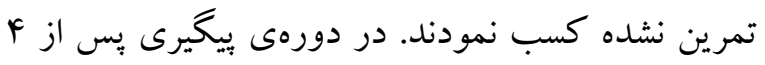
هفته، همجنان گروه آزمايش نسبت به گروه كنترل در بند اين تكاليف برترى داشت. مطالعات اخير تصويرسازى تشديد مغناطيسى كاركردى نشان داده است كه تحريك آنودال تحريك (fMRI)

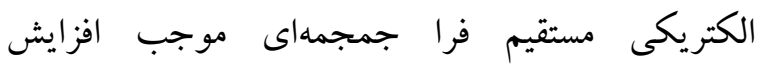
تحريك بذيرى قشرى-نخاعى 'نواحى موضعى تحريك شده و مناطق دورتر مى گردد كه مى تواند به دليل

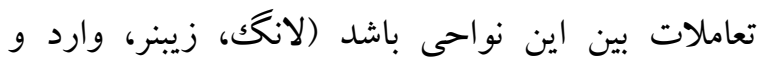

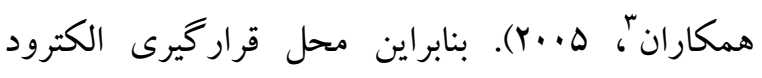
مىتواند اثرى حياتى در توزيع فضايى و مسير جريان الكتريكى كه ايجاد نمايد كه اين دو با يكديخر مى توانداند در اثربخشى تحريك، نقش تعيين كندهاى را ايفا نمايند.

\footnotetext{
1 - Martin, Liu, Alonzo

2 - corticospinal

3 -Lang, Siebner, Ward \& et al
} 
كروه اعمال تحريك الكتريكى مستقيم فرا جمجمهاى

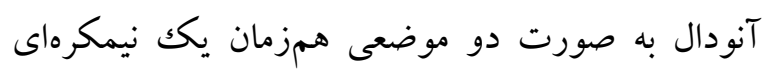

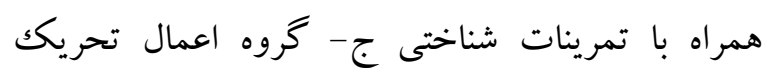
تصنعى همراه با تمرينات شناختى روش انجام تحقيق حاضر از نوع نيمه آزمايشى بود كه

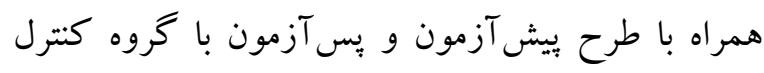

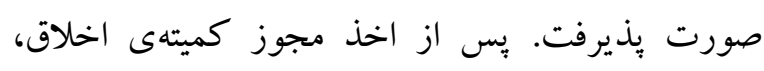

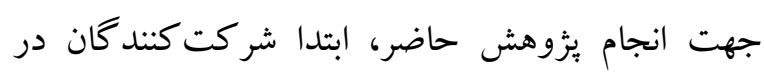

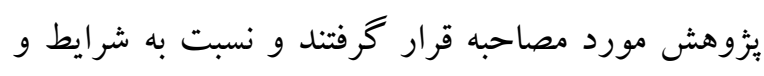

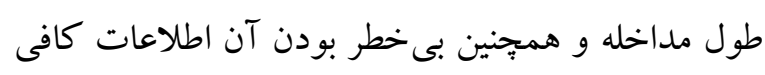

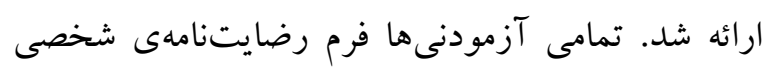

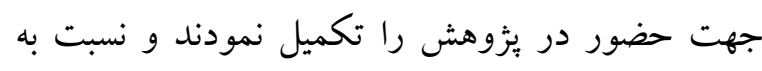

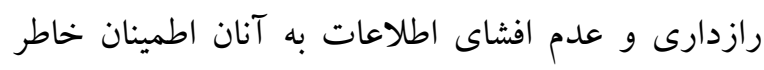
كامل داده شد آزمودنىها به صورت تصادفى در دو گروه آزمايشى شامل گروه نخست به صورت اعمال تحريك الكتريكى

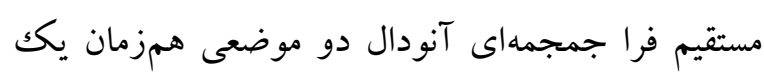
نيمكرهاى بر روى نواحى قشر حر كتى اوليه (c3) و قشر فمران

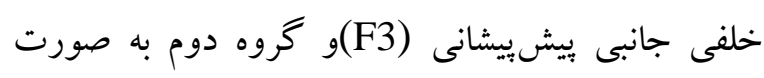

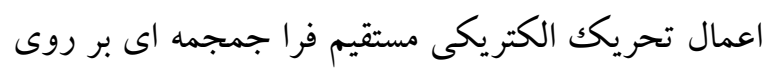

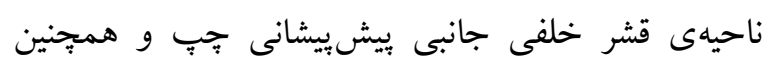

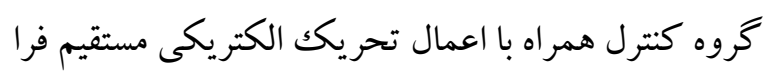
جمجمهاى به صورت تصنعى تخصيص داده شدند. به

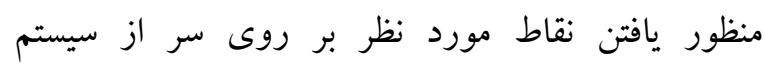

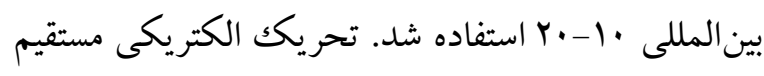

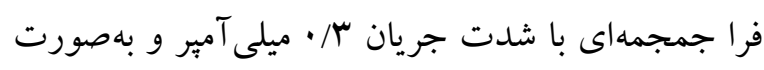

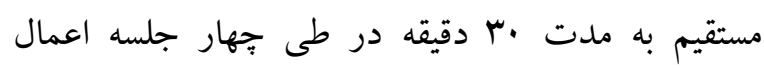

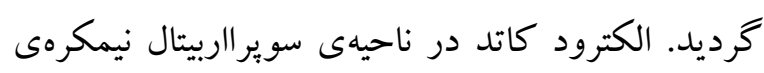

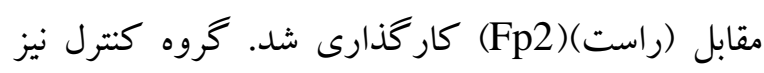

تعاملات شبكهاى موجود در كاركردهاى بيجيجيدهى عصبى همجون بازدارى پياسخ، مى تواند نقش مهمى در

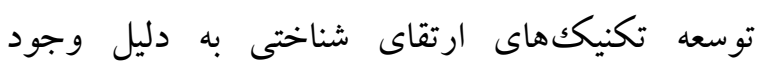
ساختارهاى شبكه اى در مغز ايفا نمايد.

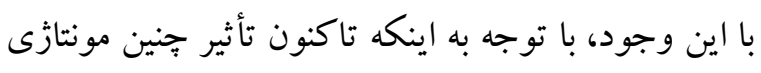

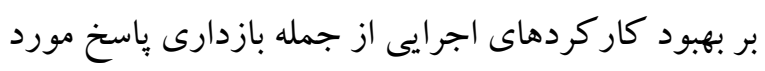

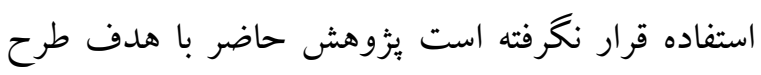
اين سؤال كه آيا اعمال تحريك الكتريكى مستقيم فرا

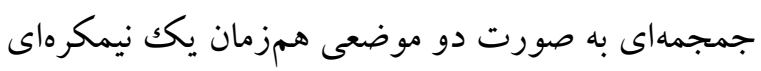

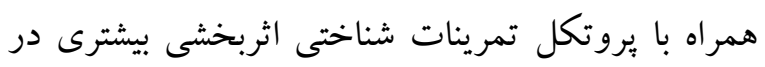

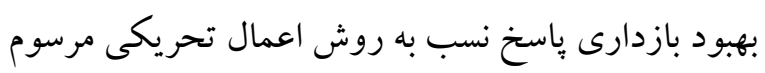
و گروه كنترل داردو يا خير.

روش جامعهى يزوهش حاضر شامل كليهى دانشجويان دانشكاه

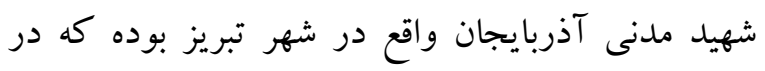

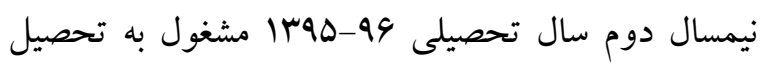
بودند. از جامعلى ذكر شده، نمونهاى به تعداد الب نفر (11)

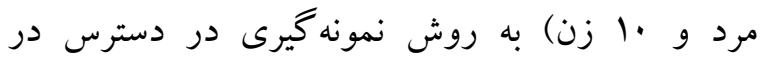

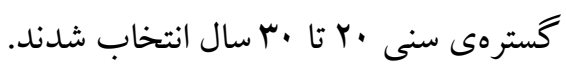

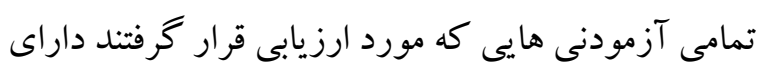

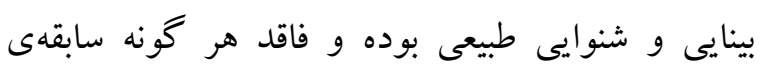

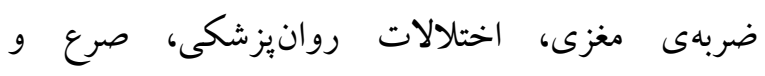
سوءمصرف الكل و يا مواد مخدر بودهاند. راست برترى إنى

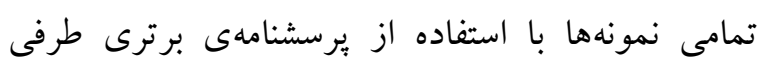

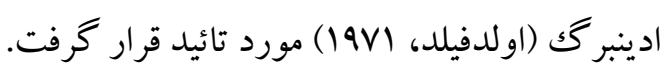

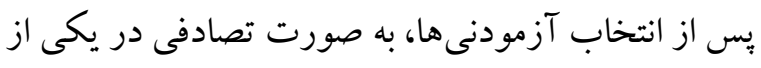

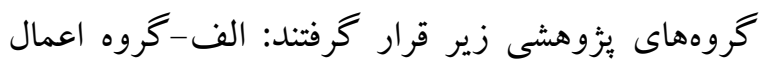

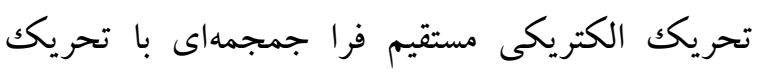

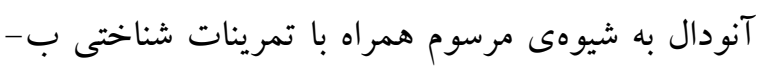


محر ككها باسخ دهند. بدين صورت كه به محر كث دايره با

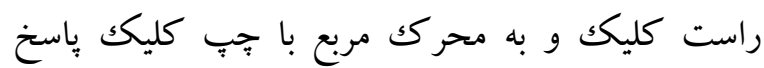

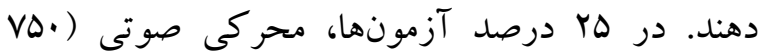

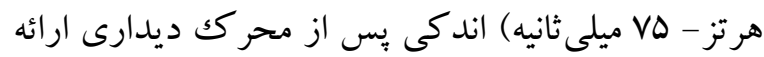
مى كردد كه هنگام شنيدن آن آزمودنى مىبايست آنسايت بلافاصله از ياسخ دادن خوددارى نمايد (استاب سيكنال). زمان بين ارائه محرك و استاب سيخنال در هر آزمون تنظيم شده است (تأخير استاب سيكنال (SSD)"). تكليف با SSD مه ميلى ثانيه آغاز مىشود و به دنبال آن بس از باسخ درست، SSD .ه ميلىثانيه افزايش مى يابد.

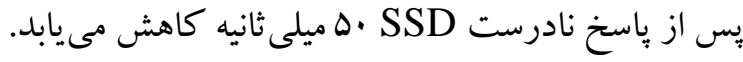

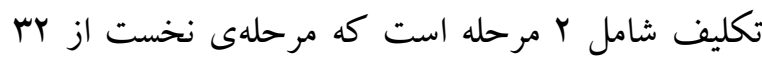

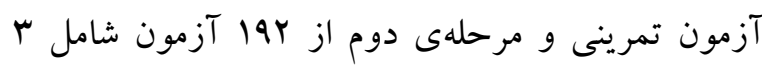
بلوكى 94 تايى با فاصلهى •ا ثانيه استراحت ميان

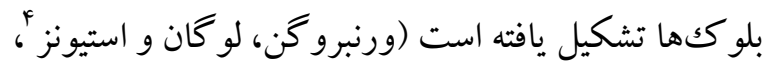

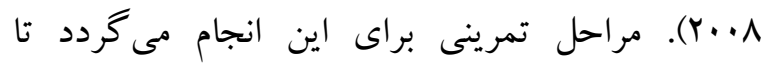

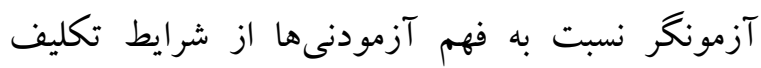
اطمينان حاصل نمايد. نقطهى تمركز (+) و محرك آرك ديدارى در وسط صفحهى نمايشخر با رنغك سفيد در

$$
\text { زمينهى سياه ارائه مى خردد. }
$$

يرسشنامه بوترى جانبى ادينبركى ؛. يرسشنامه برترى طرفى طرفى ادينبر گك براى نخستين بار توسط اولدفيلد (I9VI)

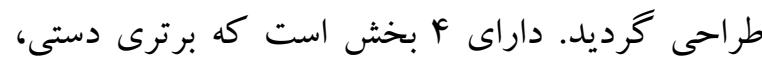

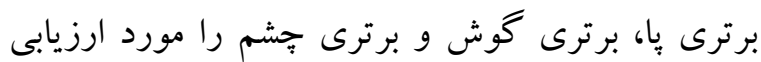
قرار مىدهد. بخش برترى دستى اين مقياس •الماده دارد كه ترجيح دستى را در نوشتن، نقاشى كردن، برت تاب كردن، قيجى كردن، مسواكك زدن، استفاده از خجاقو، استفاده از قاشق، جـارو كردن، روشـن كردن كبريـ،

3 - Stop Signal Delay(SSD)

4 - Verbruggen, Logan \& Stevens

5 - Edinburgh Handedness Inventory
تحريكك را به مدت •ب ثانيه بر روى ناحيهى قشر خلفى جانبى بيشيشانى جِّ دريافت نمودند و سبّ دستخاه به صورت خود كار قطع شد. كليهى آزمودنىها، بس از از اعمال تحريك در هر جلسه، تكليف استاب سيكنال را اجرا نمودند. جلسه ى بنجم به منظور بيخيرى اثربخشى

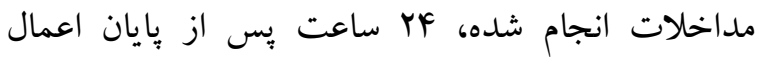
تحريك الكتريكى مستقيم فرا جمجمهاى، آزمودنىها به بهابه طور مجدد مورد ارزيابى قرار گرفتند. جهت تحليل داده IV هاى به دست آمده از نرم افزار SPSS نسخهى استفاده شد.

ابزار تحريك الكتريكى مستقيم فرا جمجمهاى (tDCS): در يزّوهش حاضر، تحريك الكتريكى مستقيم فرا جمجمهاى با استفاده از دستكاه NEUROSTIM-2 ساخت شركت

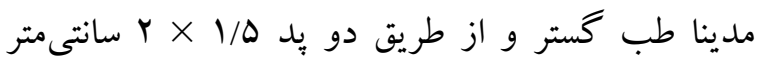

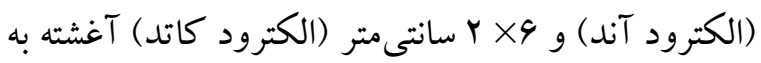
محلول نمك به شدت جريان س/ • ميلى آمبر و بهصورت

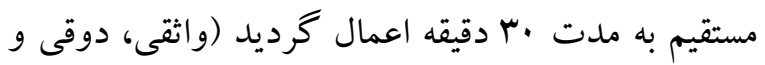

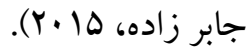
تكليف استاب ايت'؛ جهت ارزيابى توانيى بازدارى آزمودنى ها از تكليف استاب ايت (ورنبرو گن، لو كان و

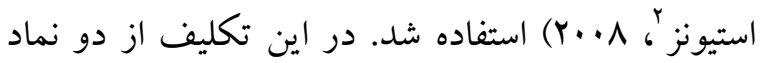

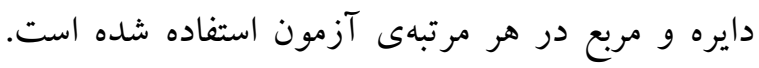

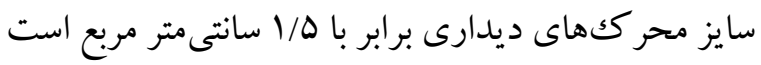
كه به مدت •هآ/ ميلى ثانيه بر روى صفحه باقى مى ماند.

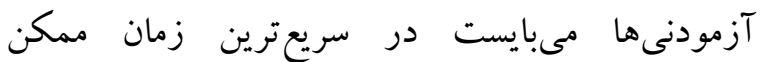
بهوسيلى كليك جِ و راست ماوس كامبيوتر به

2 - Verbruggen, Logan \& Stevens 
اثر اصلى مربوط به تكاليف استاب سيخنال و همجنين اثر تعاملى اين تكاليف معنىدار است.

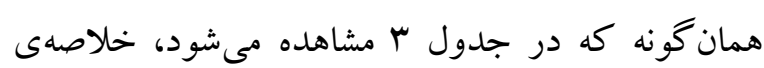
تحليل واريانس بيانگر آن است كه اثر اصلى نمرات

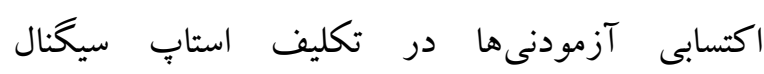

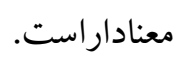

$($ Partial $\eta 2=\cdot / \wedge \mid r, P<\cdot / \cdot \cdot), F(F, V r)=$ $\mathrm{VN} / \cdot 9$ )

مقدار لامبداى ويلكز برابر با مقدار احتمال 1 + • است؛ بنابراين، با توجه به مجذورات به دست آمده، نمرات آزمودنى ها در تكليف استاب سيخنال در دو برو بروه آزمايشى و كروه كنترل تفاوت معنادارى با يكديخر دارند.

$($ Partial $\eta 2=\cdot / \wedge r \cdot, P<\cdot / \cdots,, F(\mathcal{F}, V Y)=$ fi/.9)

t به منظور مقايسه ميانخين كروه هاى ئزوهشى از آزمون مستقل استفاده شد. در جلسهى نخست بين ميانگينهاى دو گروه اعمال تحريك الكتريكى مستقيم فرا جمجمهاى آنودال به صورت دو موضعى همزمان يكى نيمكرهاى و كروه اعمال تحريك الكتريكى مستقيم فرا جمجمهاى آنودال به شيوهى مرسوم (d) (t=r/ جمجمهاى آنودال به صورت دو موضعى همزمان يكك نيمكرهاى و گروه كنترل همر اه با تحريك تصنعى تفاوت

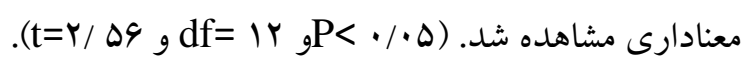
در جلسهى دوم، بين ميانگينهاى دو گرووه اعمال تحريك الكتريكى مستقيم فرا جمجمهاى آنودال بهصورت دو موضعى همزمان يكك نيمكرهاى و كروه

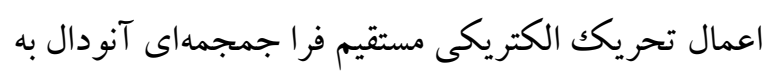

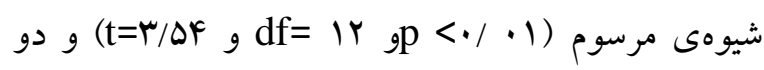

بـاز و بسـته كـردن درب قـوطى مورد سنجش قرار

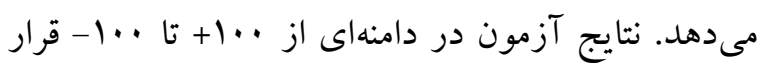

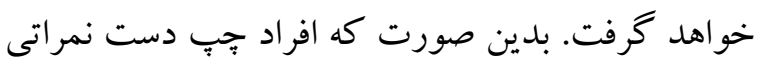
را در طيف ·F- تا · . 1-، آزمودنى هاى راست دست

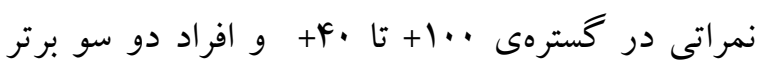

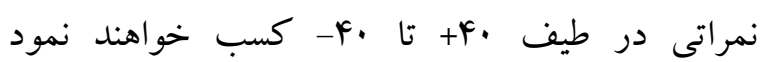
(اولدفيلد'، I9V|). سه بخش ديخر اين برسشنامه هر كدام داراى f سؤال مىباشند.

\section{يافتهها}

اطلاعات دمو گرافيك آزمودنى ها شامل ميانگين و انحر اف معيار شاخص هاى سن و جنسيت آزمودنى ها به تفكيك در جدول اكزارش شده است. ميانگين و انحراف معيار نمرات به دست آمده توسط دو كروه آزمايشى و گروه كنترل در تكاليف استاب سيخنال در جدول r قابل مشاهده است. جهت ارزيابى اثربخشى بروتكل هاى مختلف استفاده شده در بززوهش حاضر، از آزمون تجزيه و تحليل واريانس با بروناب اندازه گيرىهاى مكرر استفاده شد. ييش از آزمون تحليل واريانس، جهت رعايت بيش فرض آزمونهاى كرويت موجِلى و لون انجام شد. نتايج آزمون لون حاكى از

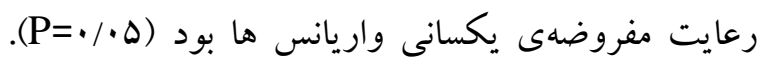
آزمون موجلى نيز نشان داد كه اين مفروضه براى تمامى

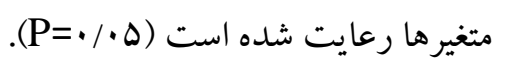

در جدول r نتايج تحليل واريانس درون گروهى با اندازه گيرىهاى مكرر به جهت بررسى معنىدارى تفاوت

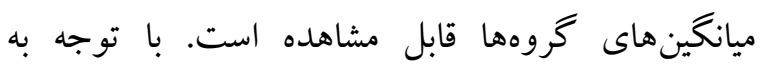
آمارهاى توصيفى فوق، نتايج جدول ب نشان مىدهد كه

${ }^{1}$ - Oldfield 
آنودال به شيوهى مرسوم و گروه كنترل همر اه با تحريك

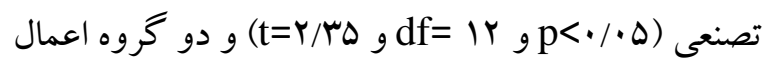
تحريك الكتريكى مستقيم فرا جمجمهاى آنودال بهصورت دو موضعى همزمان يكك نيمكرهاى و كروه كنترل همر اه با تحريك تصنعى تفاوت معنادارى مشاهده

$$
\text { شد (t=1. (t) }
$$

در جلسهى بنجم (مرحلهى بيخيرى)، بين ميانخين هاى دو كروه اعمال تحريك الكتريكى مستقيم فرا جمجمهاى آنودال به صورت دو موضعى همزمان يك نيمكرهاى و و كروه اعمال تحريك الكتريكى مستقيم فرا جمجمه اى بـ آنودال به شيوهى مرسوم ( df (t=人/r. جمجمهاى آنودال به شيوهى مرسوم و گروه كنترل همراه با تحريك تصنعى (1) كروه اعمال تحريكك الكتريكى مستقيم فرا جمجمهاى آنودال به صورت دو موضعى همزمان يكك نيمكرهاى و كروه كنترل همراه با تحريك تصنعى تفاوت معنادارى

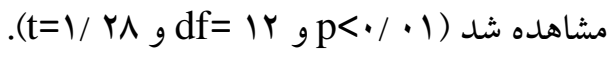

كروه اعمال تحريك الكتريكى مستقيم فرا جمجمهاى آنودال به صورت دو موضعى همزمان يكك نيمكرهاى و كروه كنترل همراه با تحريكك تصنعى تفاوت معنادارى مشاهده شد ( ا / / در جلسهى سوم، بين ميانگينهاى دو گروه اعمال تحريكك الكتريكى مستقيم فرا جمجمهاى آنودال به صورت دو موضعى همزمان يكك نيمكرهاى و گروه اعمال تحريك الكتريكى مستقيم فرا جمجمهاى آنودال به شيوهى مرسوم (1) كروه اعمال تحريك الكتريكى مستقيم فرا جمجمهاى آنودال به صورت دو موضعى همزمان يكك نيمكرهاى و كروه كنترل همراه با تحريكك تصنعى تفاوت معنادارى

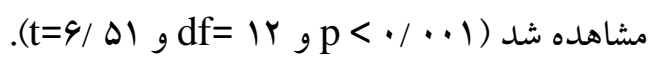
همجينين در جلسهى جهارم، بين ميانگينهاى دو گروه

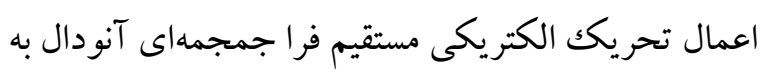
صورت دو موضعى همزمان يكك نيمكرهاى و گروه اعمال تحريك الكتريكى مستقيم فرا جمجمهاى آنودال به يه

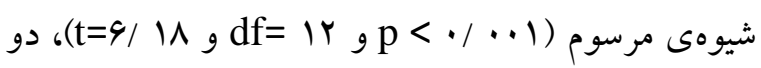
كروه اعمال تحريك الكتريكى مستقيم فرا جمجمهاى

جدول شمارهى الطلاعات دموكر افيك آزمودنى ها به تفكيك كروه ها

\begin{tabular}{|c|c|c|c|}
\hline تصمال تحرو بك & 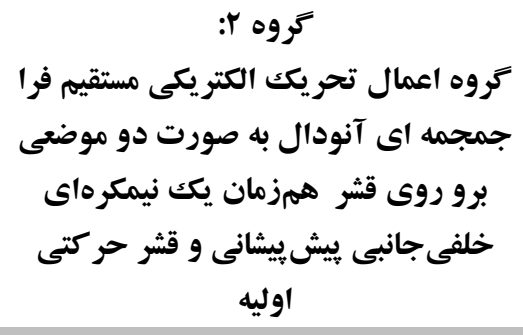 & 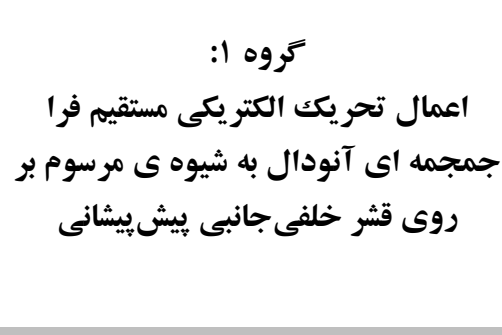 & متغير ها \\
\hline $\begin{array}{l}r r / \Lambda q \\
(r / r q)\end{array}$ & $\begin{array}{l}r r / l F \\
(r / / r)\end{array}$ & $\begin{array}{l}r Y / F r \\
(1 / q \cdot)\end{array}$ & $\begin{array}{c}\text { (سال) } \\
\text { (سن }\end{array}$ \\
\hline$F / r$ & $r / f$ & $r / F$ & $\begin{array}{c}\text { زن / (n) } \\
\text { (n) }\end{array}$ \\
\hline
\end{tabular}


جدول ץ ميانكين و انحر اف معيار نمرات در ه جلسهى مداخله

\begin{tabular}{|c|c|c|c|c|c|c|c|c|c|c|c|c|c|c|c|c|}
\hline \multicolumn{3}{|c|}{ 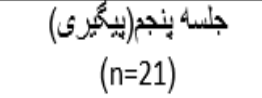 } & \multicolumn{3}{|c|}{$\begin{array}{c}\text { جلسه جهار } \\
\text { (n=21) }\end{array}$} & \multicolumn{3}{|c|}{ 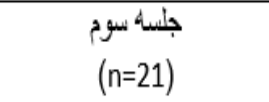 } & \multicolumn{3}{|c|}{ جلسة لومج } & \multicolumn{3}{|c|}{ جلسه نُخت } & \multicolumn{2}{|c|}{ هنتيرها } \\
\hline $\begin{array}{l}r^{r}{ }^{\prime} \\
(n=v)\end{array}$ & $\begin{array}{l}r_{0.95} \\
(n=v)\end{array}$ & 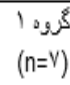 & $\begin{array}{l}r^{r} \\
(n=V)\end{array}$ & $\begin{array}{l}r_{0}{ }^{\prime} \\
(n=V)\end{array}$ & $\begin{array}{l}\log ^{\prime} \\
(n=V)\end{array}$ & $\begin{array}{l}r r^{\prime} \\
(n=V)\end{array}$ & $\begin{array}{l}r_{0.5} \\
(n=V)\end{array}$ & 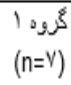 & $\begin{array}{l}r^{r} \\
(n=v)\end{array}$ & $\begin{array}{l}r \cdot r^{5} \\
(n=V)\end{array}$ & $\begin{array}{l}\log ^{\circ} \\
(n=V)\end{array}$ & $\begin{array}{l}r \text { rog } \\
(n=V)\end{array}$ & $\begin{array}{l}r_{0} \\
(n=V)\end{array}$ & $\begin{array}{l}\log ^{1} \\
(\mathrm{n}=\mathrm{v})\end{array}$ & & \\
\hline $\begin{array}{l}\{0 / 47 \\
(0 / 1 \xi)\end{array}$ & $\begin{array}{l}T r .10 \mathrm{~V} \\
(1 \leq / T r)\end{array}$ & $\begin{array}{l}r \wedge q / r) \\
(1 r / \varepsilon)\end{array}$ & $\begin{array}{l}r 90 / 0 \Lambda \\
(N / 21)\end{array}$ & $\begin{array}{l}\text { rro/av } \\
(1 \mathrm{~V} / \mathrm{T})\end{array}$ & $\begin{array}{l}r v q / T v \\
(1 / / T r)\end{array}$ & $\begin{array}{l}\{\cdots / A x \\
(1 \leq / / T)\end{array}$ & $\begin{array}{l}r \varepsilon v / / \Lambda \\
(10 / 9 T)\end{array}$ & $\begin{array}{l}r M N / 1 \Lambda \\
(Y / \cdot 1)\end{array}$ & $\begin{array}{l}\{1, / \mathrm{TV} \\
(1 N / T)\end{array}$ & $\begin{array}{l}r Y / / P . \\
(I N / 0 T)\end{array}$ & $\begin{array}{l}r i N / \varepsilon v \\
(N / V Y V)\end{array}$ & $\begin{array}{l}\{r / / R T \\
(19 / / T Y\}\end{array}$ & $\begin{array}{l}r q \alpha / 7 v \\
(1 \leqslant / 7 q)\end{array}$ & $\begin{array}{l}\{1 \varepsilon / 1.1 \\
(y / N q)\end{array}$ & 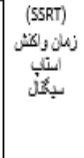 & 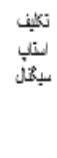 \\
\hline
\end{tabular}

\begin{tabular}{|c|c|c|c|c|c|c|c|}
\hline \multicolumn{8}{|c|}{ جدول r نتايج آزمون تحليل واريانس آميخته براى تكليف استاب سيكنال } \\
\hline اندازه اثر & sig & $\mathbf{F}$ & مجذانغين & آزادى & مجذورع مجورات & 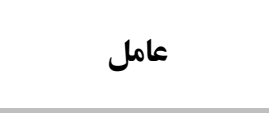 & \\
\hline - (Alr &.$/ \cdot \cdot 1$ & $V N / \cdot 4$ & $G F V F / T V$ & f & $r \Delta \wedge q Y / F \wedge$ & تكليف استاب سيكنال & \multirow{3}{*}{ درون گروهى } \\
\hline$\cdot / \Delta \Delta r$ & $\cdot / \cdot \cdot 1$ & $11 / 1$. & $Q T \cdot / F F$ & $\wedge$ & Vrar/Fa & تكليف استاب سيكنال * & \\
\hline & & & $\Delta r / Q F$ & vr & $\Delta 9 Y / / \wedge 1$ & خطا & \\
\hline \multirow[t]{2}{*}{ - /Ar. } &.$/ \cdot 1$ & $41 / \cdot 9$ & rOSVF/A. & r & DITKV/G. & كروه & \multirow[t]{3}{*}{ بين گروهى } \\
\hline & & & GTF/WV & 11 & IIYFA/QV & خطا & \\
\hline.$/ 019$ & $.1 \cdot 1$ & $F / .1$ & & & & $\begin{array}{l}\text { لامبداى ويلكز } \\
\text { (value=•/rmץ) }\end{array}$ & \\
\hline
\end{tabular}

زمودار ا: عمدلكرد آزمودنى ها در تكليفف استاب سيگذال در هـ

$$
\text { جلسهd ى مداخله }
$$

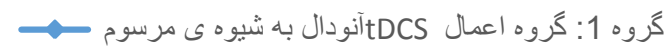

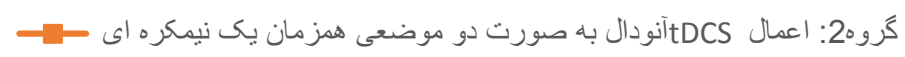

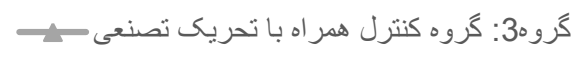

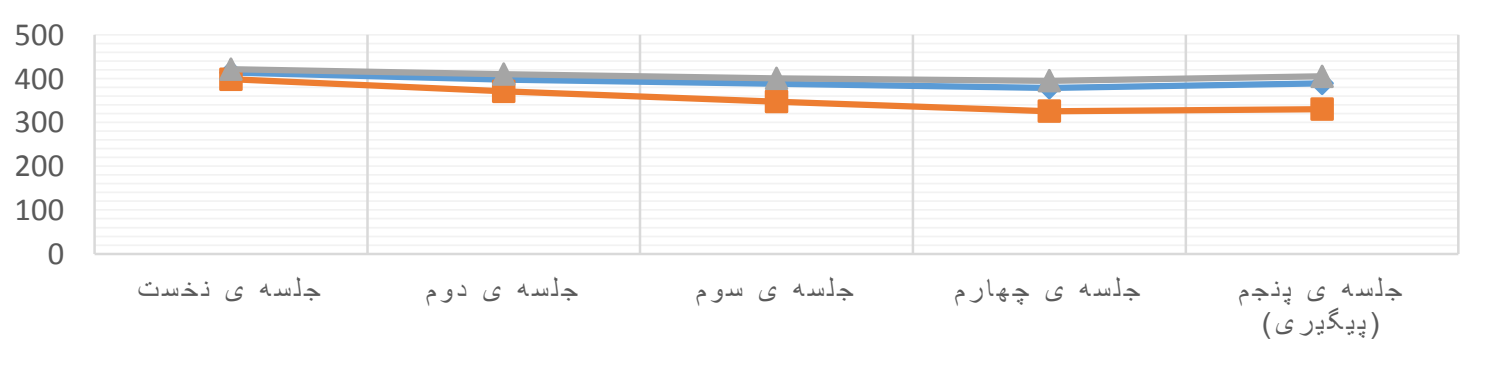


نشان دادند كه اين بهبود در عملكرد در جلسهى ينجم (مرحلهى بيخيرى) همجنان قابل توجه و معنادار بود. در درجهى نخست بثزوهش حاضر نشان داد، اعمال تحريك الكتريكى مستقيم فرا جمجمهاى به همراه انجام تمرينات شناختى، اثربخشى بيشترى نسبت به تمرينات شناختى به تنهايى دارد. اين نتايج با يافته هاى جئون و

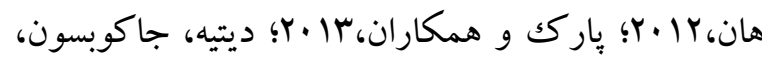

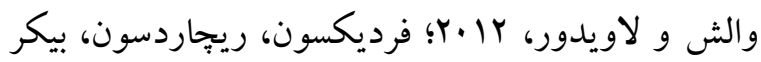

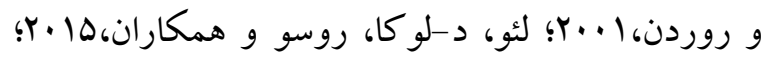

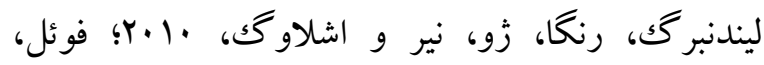

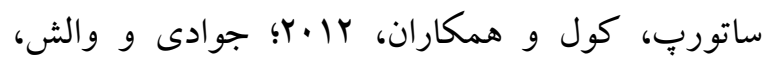

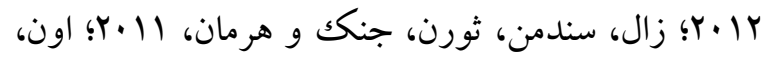

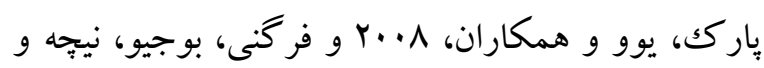
همكاران، ه •.r همسو بود. به نظر مى رسد، تحريك الكتريكى مستقيم فرا جمجمهاى مىتواند با افزايش ميزان تحريكگيذيرى كورتكسى در شبكه هاى مربوط به

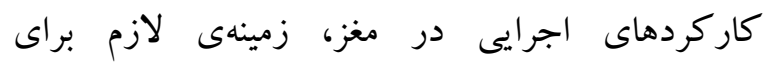
يروتكلهاى مختلف توانبخشى و ارتقا شناختى را فراهم مى سازد. از طرف ديخر يثوهش حاضر نشان داد، تحريكك آنودال همزمان نواحى درگير در يكك نيمكره، مىتواند منجر به افزايش اثربخشى تروتكل هاى توانبخشى شناختى، نسبت به اعمال تحريك الكتريكى مستقيم فرا جمجمهاى بر روى ناحيهى قشر خلفى جانبى بيش بيشانى، در عملكرد

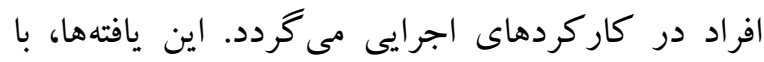
نتايج به دست آمده توسط واثقى و همكاران (ها ·Y) كه نشان داد، تحريك همزمان ناحيهى كاركردى مرتبط در علاوه بر ناحيهى مورد نظر، موجب افزايش القاى بتانسيل
نمودار 1 ميانگينهاى نمرات كسبشده در تكليف استاب سيخنال را در دو گروه آزمايشى و يكك گروه كنترل در \& مرحله اعمال تحريك الكتريكى مستقيم فرا

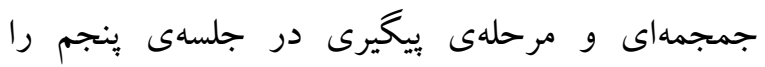
بهصورت يكك نمودار خطى نمايش مىدهد. اين نمودار نشان مىدهد كه تعداد خطاها در تكليف استاب سيخنال در گروههاى آزمايشى همر اه با اعمال تحريكك الكتريكى هـ مستقيم فرا جمجمهاى يككروند كاهشى جلسات مداخله و همجنين در جلسهى بيگيرى داشته است كه اين افزايش در عملكرد در گروه اعمال تحريك الكتريكى مستقيم فرا جمجمهاى آنودال به صورت دو موضعى همزمان يكك نيمكرهاى بهصورت برجستهترى بوده است.

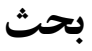

يثزوهش حاضر با هدف مقايسهى بيروتكلهاى اعمال تحريكك الكتريكى مستقيم فرا جمجمهاى به صورت دو موضعى همزمان تكك نيمكرهاى بر روى نواحى قشر حركتى اوليه و قشر خلفى جانبى بيشيشيشى و و روش مرسوم (تحريكك قشر خلفى جانبى بيش ييشانى) به همراه تمرينات شناختى انجام گرفت. نتايج يثوهش حاضر نشان داد كه دو گروه هاى آزمايشى همر اه با اعمال تحريكك الكتريكى مستقيم فرا جمجمهاى به صورت دو موضعى همزمان تكك نيمكرهاى بر روى همر بمان نواحى قشر حر كتى اوليه و قشر خلفى جانبى بيشيشيشانى و گروه اعمال تحريكك الكتريكى مستقيم فرا جمجمه اى به صورت مرسوم نسبت به گروه كنترل عملكرد بهترى را در تكليف استاب سيكنال از خود نشان دادند. از طرف ديخر، گروه همر اه با اعمال تحريك الكتريكى مستقيم فرا جمجمه اى به صورت دو موضعى همزمان تك نيمكرهاى نسبت به روش مرسوم عملكرد بهترى از خود 
از طرف ديخر يافته هاى حاصل از مرحلهى بيخيرى نيز

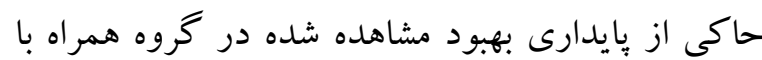

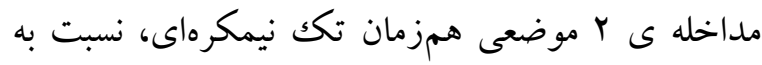

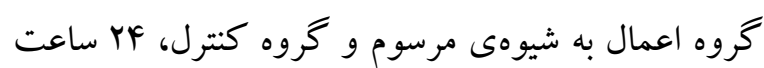

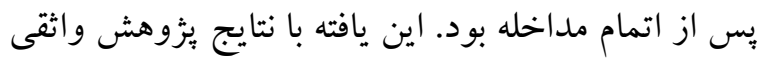

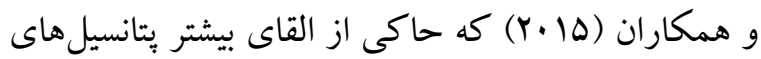

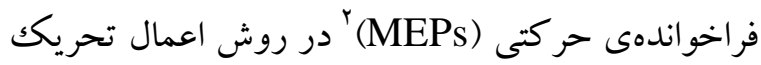
الكتريكى مستقيم فرا جمجمهاى آنودال بهصورت دو

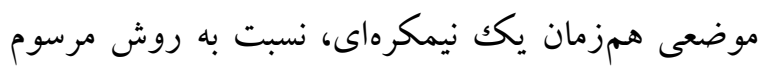
كه حداقل به مدت YF ساعت ادامه داشت، همسو بود.

\section{نتيجه كيرى}

به نظر مىرسد، استفاده از بروتكل تحريك الكتريكى مستقيم فرا جمجمهاى همزمان ب موضعى تكك نيمكرهاى مى تواند اثربخشى تمرينات شناختى را افزايش داده و

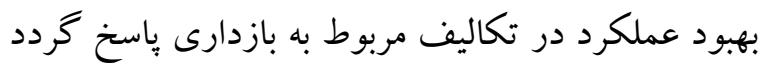
بنابراين با توجه به اثربخشى ثروتكل معرفى شدده، ييشنهاد

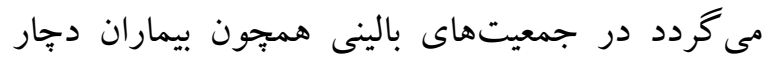
بيش فعالى و اختلالات خوردن، بيماران دجار سكتهى مغزى و باركينسون مورد كار آزمايى بالينى قرار كيرد. از

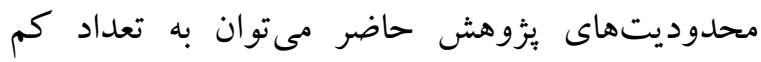

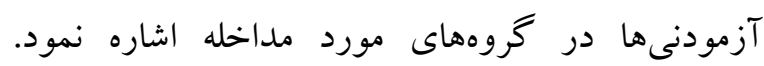
ييشنهاد مى گردد در يزوهشهاى آتى در ابعاد گستردهتر

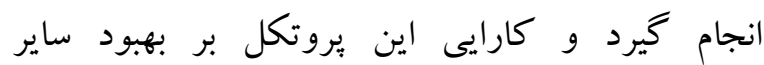
عملكردهاى شناختى مورد بررسى قرار گيرد.

سباسكزارى
هاى فراخواندهى حركتى (MEPs)' در افراد بهنجار مى گردد، همسو بود. به نظر مىرسد كه ناحيهى حر كتى اوليه در كاركردهاى اجرايى از جمله بازدارى باسخ افراد نقش مهمى ايفا مىنمايد. شايد بتوان دليل جنين امرى را در تعاملات كاركردى و عصبى ميان اين نواحى و ناحيهى قشر خلفى جانبى بيشيشانى دانست كه در يزوهش اخير كو كلتا و همكاران (19 (Y)، مورد توجه قرار گرفت. مطالعهى دام و استريك و هى و همكاران (به نقل از واثقى و همكاران، 10 أr ) نشان داد، كورتكس ناحيهى بيش حركتى به دو قسمت بشتى و شكمى تقسيم مى شود كه ناحيه بشتى آن خروجىاش را به ناحيهى قشر

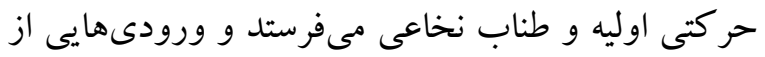
ناحيهى قشر خلفى جانبى بيشيشانى دريافت مى كند. مدولاسيون مربوط به توجه در ناحيهى قشر خلفى جانبى يشيشيشانى و داده هاى مربوط به آمادكى حركتى در ناحيهى بشتى كور تكس بيش حر كتى توسط ناحيهى قشر حركتى اوليه دريافت مى گردد. درنتيجهى حنين ساختار كاركردى، به نظر مىرسد كه تحريك آنودال همزمان ناحيه قشر خلفى جانبى بيشيشانى و قشر حركتى اوليه مىتواند، منجر به فعالسازى مسير عصبى قشر خلفى لنى جانبى ويشيشانى_ قشر بيش حركتى_ ناحيه حركتى اوليه گردد و تحريك بذيرى اين نواحى را افزايش دهد (واثقى و همكاران، وجود جنين مسيرهايى بين اين دو ناحيه، تحريك دو ناحيه به طور همزمان سبب فعالسازى بيشتر و در نتيجه بهبود در كاركردهاى مربوط به بازدارى باسخ گر دد. 
aphasia a double-blind, sham-controlled study. Stroke, 42(3), 819-821.

Goldman-Rakic, PS. (1995). Architecture of the prefrontal cortex and the central executive. Annals of the New York Academy of Sciences, 769(1), 71-84.

Gorelick, PB, \& Bowler JV. (2008). Advances in vascular cognitive impairment 2007. Stroke, 39(2), 279-282.

Gothe, N, Pontifex MB, Hillman C, \& McAuley E. (2013). The acute effects of yoga on executive function. Joumal of physical activity and health, 10(4), 488-495.

Javadi, AH, \& Walsh V. (2012). Transcranial direct current stimulation (tDCS) of the left dorsolateral prefrontal cortex modulates declarative memory. Brain stimulation, 5(3), 231-241.

Jeon, SY, \& Han SJ. (2012). Improvement of the working memory and naming by transcranial direct current stimulation. Annals of rehabilitation medicine, 36(5), 585-595.

Kukleta, M, Damborská A, Roman R, Rektor IZ \& Brázdil M. (2016). The primary motor cortex is involved in the control of a non-motor cognitive action. Clinical Neurophysiology, 127(2), 1547-1550.

Kuo, MF,Paulus W, \& Nitsche MA. (2014). Therapeutic effects of non-invasive brain stimulation with direct currents (DCS) in neuropsychiatric diseases. Neuroimage, 85(6), 948-960.

Kwon, YH., \& Kwon JW. (2013). Response inhibition induced in the stop-signal task by transcranial direct current stimulation of the presupplementary motor area and primary sensoriomotor cortex. Joumal of physical therapy science, 25(9), 1083-1086.

Lang, N, Siebner HR, Ward NS, Lee L, Nitsche MA, Paulus W, Frackowiak RS. (2005). How does transcranial DC stimulation of the primary motor cortex alter regional neuronal activity in the human brain? European Journal of Neuroscience, 22(2), 495-504.

Leo, A, De Luca R, Russo M, Naro A, Bramanti P, \& Calabrò RS. (2015). Role of tDCS in

$$
\begin{aligned}
& \text { از شر كت مدينا طب كستر كه دستگاه نورواستيم Y را در } \\
& \text { اختيار ما قرار دادند و در هيزوهش حاضر ما را يارى } \\
& \text { رساندند، كمال تشكر و قدردانى راداريم. }
\end{aligned}
$$

\section{References}

Anderson, P. (2002). Assessment and development of executive function $(\mathrm{EF})$ during childhood. Child neuropsychology, 8(2), 71-82.

Bindman, LJ, Lippold O, \& Redfeam J. (1964). The action of brief polarizing currents on the cerebral cortex of the rat (1) during current flow and (2) in the production of long-lasting after-effects. The Joumal of physiology, 172(3), 369 .

Bracy, OL. (1983). Computer based cognitive rehabilitation. Cognitive Rehabilitation, 1(1), $7-8,18$.

Ditye, T, Jacobson L, Walsh V, \& Lavidor M. (2012). Modulating behavioral inhibition by tDCS combined with cognitive training. Experimental brain research, 219(3), 363-368.

Föel, A, Suttorp W, Kohl O, Kürten J, Lohmann H, Breitenstein C, \& Knecht S. (2012). Noninvasive brain stimulation improves objectlocation leaming in the elderly. Neurobiology of aging, 33(8), 1682-1689.

Fregni, F, Boggio PS, Nitsche M, Bermpohl F, Antal A, Feredoes E, Paulus W. (2005). Anodal transcranial direct current stimulation of prefrontal cortex enhances working memory. Experimental brain research, 166(1), 23-30.

Fridriksson, J, Richardson JD, Baker JM, \& Rorden C. (2011). Transcranial direct current stimulation improves naming reaction time in fluent

potentiating poststroke computerized cognitive rehabilitation: Lessons leamed from a case study. Applied Neuropsychology: Adult, 1-5.

Lezak, MD. (2004). Neuropsychological assessment: Oxford University Press, USA.

Lindenberg, R, Renga V, Zhu L, Nair D, \& Schlaug G. (2010). Bihemispheric brain stimulation 
facilitates motor recovery in chronic stroke patients. Neurology, 75(24), 2176-2184.

Martin, DM, Liu R, Alonzo A, Green M, Player MJ, Sachdev P, \& Loo CK. (2013). Can transcranial direct current stimulation enhance outcomes from cognitive training? A randomized controlled trial in healthy participants. Intemational Joumal of Neuropsychopharmacology, 16(9), 19271936.

Naglieri JA, Goldstein S. (2014). Handbook of executive functioning. New York: Springer Science \&Business Media Press, 29-44

Nitsche, M A, Liebetanz D, Antal A, Lang N, Tergau F, \& Paulus W. (2003). Modulation of cortical excitability by weak direct current stimulationtechnical, safety and functional aspects. Suppl Clin Neurophysiol, 56(3), 255-276.

Nitsche, M, \& Paulus W. (2000). Excitability changes induced in the human motor cortex by weak transcranial direct current stimulation. The Journal of physiology, 527(3), 633-639.

Nitsche, MA, \& Fregni F. (2007). Transcranial Direct Cument Stimulation-An Adjuvant Tool for the Treatment of Neuropsychiatric Diseases? Cument Psychiatry Reviews, 3(3), 222-232.

Nitsche, MA, \& Paulus W. (2001). Sustained excitability elevations induced by transcranial DC motor cortex stimulation in humans. Neurology, 57(10), 1899-1901.

Ohn, SH, Park CI, Yoo WK, Ko MH, Choi KP, Kim GM, Kim YH. (2008). Time-dependent effect of transcranial direct current stimulation on the enhancement of working memory. Neuroreport, 19(1), 43-47.

Oldfield, R. C. (1971). The assessment and analysis of handedness: the Edinburgh inventory. Neuropsychologia, 9(1), 97-113.

Park, S.-H., Koh, E.-J., Choi, H.-Y., \& Ko, M.-H. (2013). A double-blind, sham-controlled, pilot study to assess the effects of the concomitant use of transcranial direct current stimulation with the computer assisted cognitive rehabilitation to the prefrontal cortex on cognitive functions in patients with stroke. Joumal of Korean Neurosurgical Society, 54(6), 484-488.

Reti, I. M., \& Chang, A. D. (2015). Introduction to brain stimulation. Brain Stimulation, Methodologies and Interventions, 3(5), 1-12

Utz, K. S., Dimova, V., Oppenländer, K., \& Kerkhoff, G. (2010). Electrified minds: transcranial direct current stimulation (tDCS) and galvanic vestibular stimulation (GVS) as methods of non-invasive brain stimulation in neuropsychology - a review of current data and future implications. Neuropsychologia, 48(10), 2789-2810.

Vaseghi, B., Zoghi, M., \& Jaberzadeh, S. (2015). The effects of anodal-tDCS on corticospinal excitability enhancement and its after-effects: conventional vs. unihemispheric concurrent dual-site stimulation. Frontiers in Human Neuroscience, 9, 533.

Verbruggen, F., Logan, G. D., \& Stevens, M. A. (2008). STOP-IT: Windows executable software for the stop-signal paradigm. Behavior research methods, 40(2), 479-483.

Zaehle, T., Sandmann, P., Thome, J. D., Jäncke, L., \& Hermann, C. S. (2011). Transcranial direct current stimulation of the prefrontal cortex modulates working memory performance: combined behavioural and electrophysiological evidence. BMC neuroscience, 12(1), 1 .

Ziemann, U., Paulus, W., Nitsche, M. A., PascualLeone, A., Byblow, W. D., Berardelli, A., Rothwell, J. C. (2008). Consensus: motor cortex plasticity protocols. Brain stimulation, 1(3), 164-182.

Zoltan, B. (2007). Vision, Perception, and Cognition: A Manual for the Evaluation and Treatment of the Adult with Acquired Brain Injury: Eurospan Group. 